\title{
Sweet taste of prosocial status signaling : When eating organic foods makes you happy and hopeful
}

\section{Puska, Petteri}

2018-02-01

Puska, P , Kurki , S , Lähdesmäki , M , Siltaoja , M \& Luomala, H 2018 , ' Sweet taste of prosocial status signaling: When eating organic foods makes you happy and hopeful ' , Appetite , vol. 121 , pp. 348-359 . https://doi.org/10.1016/j.appet.2017.11.102

http://hdl.handle.net/10138/321625

https://doi.org/10.1016/j.appet.2017.11.102

cc_by_nc_nd

acceptedVersion

Downloaded from Helda, University of Helsinki institutional repository.

This is an electronic reprint of the original article.

This reprint may differ from the original in pagination and typographic detail.

Please cite the original version. 


\section{Accepted Manuscript}

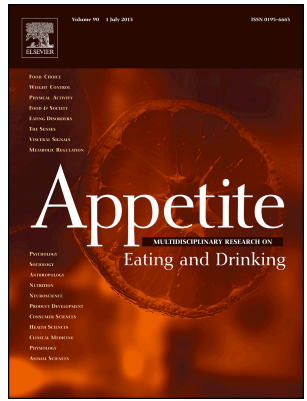

Sweet taste of prosocial status signaling: When eating organic foods makes you happy and hopeful

Petteri Puska, Sami Kurki, Merja Lähdesmäki, Marjo Siltaoja, Harri Luomala

PII: S0195-6663(17)30524-X

DOI: $\quad$ 10.1016/j.appet.2017.11.102

Reference: $\quad$ APPET 3699

To appear in: Appetite

Received Date: 4 April 2017

Revised Date: 24 October 2017

Accepted Date: 21 November 2017

Please cite this article as: Puska P., Kurki S., Lähdesmäki M., Siltaoja M. \& Luomala H., Sweet taste of prosocial status signaling: When eating organic foods makes you happy and hopeful, Appetite (2017), doi: 10.1016/j.appet.2017.11.102.

This is a PDF file of an unedited manuscript that has been accepted for publication. As a service to our customers we are providing this early version of the manuscript. The manuscript will undergo copyediting, typesetting, and review of the resulting proof before it is published in its final form. Please note that during the production process errors may be discovered which could affect the content, and all legal disclaimers that apply to the journal pertain. 
Title: Sweet taste of prosocial status signaling: When eating organic foods makes you happy and hopeful

Author names and affiliations: Petteri Puska ${ }^{a,{ }^{*}}$, Sami Kurki ${ }^{\text {b, }}$ Merja Lähdesmäki ${ }^{\mathrm{b}}$, Marjo Siltaoja ${ }^{c}$, Harri Luomala ${ }^{a}$

${ }^{\text {a }}$ University of Vaasa, Department of Marketing, Foodwest Ltd, Vaasantie 1 C, 60100 Seinäjoki, Finland

${ }^{\mathrm{b}}$ University of Helsinki, Ruralia Institute, Kampusranta 9 C, 60320 Seinäjoki, Finland

${ }^{c}$ University of Jyväskylä (JSBE), Corporate Environmental Management, Mattilanniemi 2, 40014 Jyväskylä, Finland

* Corresponding author.

E-mail addresses: petteri.puska@uva.fi (P. Puska), sami.p.kurki@helsinki.fi (S. Kurki), merja.lahdesmaki@helsinki.fi (M. Lähdesmäki), marjo.siltaoja@jyu.fi (M. Siltaoja), harri.luomala@uva.fi (H. Luomala). 


\title{
you happy and hopeful
}

\begin{abstract}
As the current research suggests that there are links between prosocial acts and status signaling (including sustainable consumer choices), we empirically study (with three experiments) whether food consumers go green to be seen. First, we examine how activating a motive for status influences prosocial organic food preferences. Then, we examine how the social visibility of the choice (private vs. public) affects these preferences. We found that when consumers' desire for status was elicited, they preferred organic food products significantly over their nonorganic counterparts; making the choice situation visible created the same effect. Finally, we go beyond consumers' evaluative and behavioral domains that have typically been addressed to investigate whether this (nonconscious) "going green to be seen" effect is also evident at the level of more physiologically-driven food responses. Indeed, status motives and reputational concerns created an improved senso-emotional experience of organic food. Specifically, when consumers were led to believe that they have to share their organic food taste experiences with others, an elevation could be detected not only in the pleasantness ratings but also in how joyful and hopeful they felt after eating a food sample. We claim that the reason for this is that a tendency to favor organic foods can be viewed as a costly signaling trait, leading to flaunting about one's prosocial tendencies. According to these findings, highlighting socially disapproved consumption motives, such as reputation management, may be an effective way to increase the relatively low sales of organic foods and thereby promote sustainable consumer behavior.
\end{abstract}

Keywords: organic food, prosocial signaling, status, motivational priming, senso-emotional experience, nonconscious behavior 


\section{Introduction}

Current food consumption and production are not at a sustainable level (Reisch, Eberle, \& Lorek, 2013): they contribute to climate change and environmental degradation (see Thøgersen, 2017). In fact, food is one of the three consumption domains, together with housing and transportation, with the most significant impact on the environment (cf. Tukker, 2015). Transitioning toward organic food consumption would offer a more sustainable alternative (see Scalco, Noventa, Sartori, \& Ceschi, 2017). However, in spite of the positive general attitudes toward organically produced foods (see Marian, Chrysochou, Krystallis, \& Thøgersen, 2014) their consumption has still remained relatively low. In the world's leading "organic country" (Denmark), the share of the consumed food accounted for by organic foods was $7.6 \%$ in 2014 (IFOAM, 2016). Although the share of organic food has steadily increased during the last years, this growth has remained moderate (see Lee \& Hwang, 2016). The critical question, then, is how to increase this share and advance more sustainable food consumption?

The high price of organic food is often suggested to be the major barrier to increasing their consumption (Aschemann-Witzel \& Zielke, 2017; Jensen, Denver, \& Zanoli, 2011; Magnusson, Arvola, Hursti, Aberg, \& Sjoden, 2002; Padel \& Foster, 2005). In the US, for example, it has been calculated that organic food is $40-175 \%$ more expensive than conventionally produced food (Magkos, Arvaniti, \& Zampelas 2006). Other barriers that have often been mentioned include availability problems (e.g., Fotopoulus \& Krystallis, 2002) and lack of clarity relating to organic labels, such as skepticism and lack of trust toward them (Hughner, McDonagh, Prothero, Shultz, \& Stanton, 2007; Nuttavutshitsit \& Thøgersen, 2017) or limited awareness about them (Schleenbecker \& Hamm, 2013). Why, then, are organically produced foods favored? The most common purchase reasons self-reported by consumers include superior taste, healthiness, food safety, animal welfare and environmental benefits (e.g., Boizot-Szantai, Hamza, \& Soler, 2017; Hemmerling, Hamm, \& Spiller, 2015) - the latter two can be considered to reflect prosocial, altruistic motives, whereas the former three are more selfish reasons (Kareklas, Carlson, \& Muehling, 2014).

In the light of recent findings, it is however possible that organic foods are also favored due to other motives that are nonconscious or socially disapproved. We suggest that understanding these more socially oriented motives will reveal means to increase their popularity. The top purchase reasons for environmentally friendly hybrid cars have often been shown to be reputational (Maynard, 2007). In a similar vein, the major motive to participate in prosocial acts, such as charity donations (Ariely, Bracha, \& Meier, 2009; Van Vugt \& Iredale, 2013) or volunteering (Bereczkei, Birkas, \& Kerekes, 2010), has in many cases been demonstrated to be status signaling. Perhaps the most illustrative example of this "prosocial status signaling" (i.e., attaining status through seemingly unselfish acts) is provided by the study of Griskevicius, Tybur, and Van den Bergh (2010). It revealed that after the nonconscious status motives of the study participants were activated, they preferred less luxurious green products over more luxurious nongreen products across a wide range of product categories (cars, washing machines, table lamps, etc.). Inconsistent with traditional status-signaling views ${ }^{1}$ (see Mandel, Petrova, \& Cialdini, 2006; Rucker \& Galinsky, 2008; Wang \& Wallendorf, 2006), but in line with the costly signaling theory (e.g., Hardy \& Van

\footnotetext{
${ }^{1}$ Consumers' tendency to signal about their status through consumption choices is an extensively researched topic. The vast majority of this research suggests that luxury brands, socially visible (expensive) consumer durables and the like "conspicuous products" are the main vehicles for such behaviors. Openly selfish motives, such as self-indulgence, are believed to motivate consumers to send a status signal.
} 
Vugt, 2006; Roberts, 1998; Soler, 2013), eliciting the desire for status led consumers to shy away from luxury and to choose an alternative that benefits everyone.

The previous discussion leads to the obvious question that we aim to study: can prosocial status signaling occur in the mundane consumption context of organic food? Considering that, in spite of the higher price, organic foods are shopped for as effortlessly and automatically as their conventionally produced alternatives (Thøgersen, Jorgensen, \& Sandager, 2012), the idea that motivational priming increases preference for them sounds intriguing.

However, this is not necessarily the whole story. Nonconscious exposure to a wellknown brand (cf. universally known organic foods) has been shown to be able to make people more creative. In a study by Fitzsimons, Chartrand, and Fitzsimons (2008), Apple-primed study participants performed better in their appointed tasks than IBM-primed participants. In the food realm, when consumers' nonconscious status motives were activated, they started to signal their status through the size of food portions; exposure to a power prime got them to choose bigger food portions (Dubois, Rucker, \& Galinsky, 2012).

Although there is now a body of research showing that activating a nonconscious goal can create a variety of reactions and responses, including food and eating-related behaviors (e.g., Schloesser, 2015; Sengupta \& Zhou, 2007; Stöckli, Stämpfli, Messner, \& Brunner, 2016), no evidence can be found for its effects on consumers' senso-emotional food experience (including traditional hedonic liking and more specific taste emotions). This is surprising particularly for two reasons. First, both sensory and emotional reactions to foods have generated rich research fields during the last decades (see Köster \& Mojet, 2015; Schouteten, 2017). Second, studies drawing from Sirgy's (1982) self-congruity theory conducted in the sensory realm - have implied for some time that (in)congruity between food brands' symbolic content and consumers' values (cf. motivations) may lead to a distinct sensory level experience (Allen, Gupta, \& Monnier, 2008; Paasovaara, Luomala, Pohjanheimo, \& Sandell, 2012). For this reason, we also aim to study whether prosocial status signaling - the "going green to be seen" effect - manifests in ways that go beyond wellestablished evaluative and behavioral domains. Well-acknowledged, usually positive impact of organic label on taste perception (e.g., Ellison, Duff, Wang, \& White, 2016; Lee, Shimizu, Kniffin, \& Wansink, 2013) makes focusing on this issue extremely interesting.

To conclude, we suggest in this paper - and we will empirically reveal through three experiments for the very first time - that nonconscious activating of desire for status leads prosocial status signaling through favoring organic foods, which also manifests - intriguingly - in improvements in their senso-emotional experience (see Thomson, 2007). During this process, we draw from the newest evolutionary psychology (see Saad, 2016), priming and food research. This integration of ideas from motivational priming, costly signaling, (in)congruity accounts and food-elicited effect theories to elucidate how status concerns, reputational goals and senso-emotional experiences uniquely combine in this mundane consumption context of organic food represents the major contribution of this study. Next, we open the conceptual underpinnings leading to three research hypotheses.

\section{Conceptual underpinnings}

\subsection{Organic food as a costly signal}

Even though status signaling and sustainable consumer choices seem poorly compatible with each other, recent research has shown that important links exist between them. When the New York Times reported the top five reasons for buying a hybrid Prius, concern for the environment was last on the list. Instead, the Prius owners proudly reported that the most 
important reason for buying one was because "it makes a statement about me" (Maynard, 2007). In a similar vein, the study of Griskevicius et al. (2010) revealed that after the study participants were primed with status motives, they preferred less luxurious green products over more luxurious nongreen products across a wide range of categories (e.g., cars, washing machines, table lamps). Status motives increased the desire for green products, especially when they were more (but not less) expensive than the nongreen products. Consumers' willingness to pay for a "green" signal and their status-motivated desire to display "austerity rather that ostentation" has been identified in other studies, too (Delgado, Harriger, \& Khanna, 2015; Elliot, 2013; Sexton \& Sexton, 2014; Van der Wal, Van Horen, \& Grinstein, 2016).

Why then do consumers want to communicate about their status by favoring sustainable brands, products and services? It has been suggested (e.g., Maynard, 2007) that a person acting like this signals to others that he or she is a prosocial individual. Having a prosocial reputation can be extremely useful: people construed as cooperative and helpful are perceived as more desirable friends, allies, leaders and romantic partners (see Griskevicius et al., 2010). Thus, signaling about one's prosocial behavior may also be a viable strategy for attaining status. In other words, it offers an opportunity to be respected and honored in the peer group that, in turn, improves one's chances of attaining a leading position and the consequent resources.

In the light of these status-enhancing benefits, one might think that people would actually compete to be seen as being as prosocial as possible. Indeed, this has occurred throughout different cultures and time periods: this behavior is known as competitive altruism (e.g., Hardy \& Van Vugt, 2006; Roberts, 1998). The existence of competitive altruism in human life is often explained through the lens of costly signaling theory (Zahavi, 1975). In the field of consumer research, it has been shown that favoring green (Griskevicius et al., 2010) and luxury products (Lee, Ha, \& Megehee, 2015; Nelissen \& Meijers, 2011) can act as costly signals of status. According to this perspective, an altruistic act communicates both about a person's prosociality and his/her ability to incur greater costs without a negative impact on fitness (cf. wealth) (Bliege Bird \& Smith, 2005).

Our key theoretical assumption is that favoring organic foods can also act as a costly signal of status. To qualify as such, however, four criteria must be met (Bliege Bird \& Smith, 2005). First, the signal must be observable. Organic foods meet this criterion because they are equipped with distinct visual labels and are often placed in separate locations in grocery stores (cf. Van der Wal et al., 2016). The second criterion relates to the fact that the signal must be costly to display for the signaler. The price premium that consumers pay for organic foods (Magkos et al., 2006) makes them prototypical examples of costly signals. Furthermore, as the availability of organic foods is in many cases more limited than that of conventional foods (Hjelmar, 2011), consumers may have to sacrifice a considerable amount of time and energy resources to finding them. Organic food production is also strictly regulated (i.e., there are hardly any cheaper forgeries with better availability). The third criterion is that it must be associated with some unobservable, yet desirable quality of an individual such as good genes or physical health or some status-enhancing, socially highly valued trait. According to the final criterion, a costly signal must ultimately yield a fitness benefit to its signaler. This benefit derives from the effects of signaling about one's habits on the behavior of signal receivers.

Concrete support for the claim that the latter criteria are also met in the case of favoring organic foods has been received from the study of Puska, Kurki, Lähdesmäki, Siltaoja, and Luomala (2016). This experimental study revealed that a male who signaled about his status through favoring organic foods - compared to a male who did not - was not only perceived as more respected and altruistic (the third criterion), but was also more favorably treated. 
Sending this costly, prosocial signal led the males receiving the signal to donate more money to him in a charity donation task (the fourth criterion). Hence, also in this everyday, smaller price tag consumption context, the criteria are seen to be met well. To conclude, because the current research suggests that there are links between prosocial acts (including environmental behaviors) and competition for status - and because indications from the status-enhancing potential of favoring organic foods have been received - we hypothesize as follows:

H1. Activating consumers' status motives will increase the likelihood of preferring organic foods (compared to nonorganic foods).

\subsection{Role of social visibility}

According to costly signaling theory, one of the key factors in how status motives should influence one's decisions is the extent to which the choice situation is socially visible to others (cf. Kimura et al., 2012). Public purchases can conspicuously signal characteristics about the buyer to an immediate audience (i.e., to create reputational benefits). In contrast, if the purchases are made privately without any witnesses, the signaling aspects of the choice are much less salient (i.e., reputational benefits do not arise). As the purchase of green products enables a person to signal that $\mathrm{s} / \mathrm{he}$ is both willing and able to buy a product that benefits others at a cost to his/her personal resources, activating a motive for status might lead people to engage in conspicuous conservation (i.e., public proenvironmental act).

Indeed, in line with the previous assumption, Griskevicius et al. (2010) showed that activating status motives led people to choose green products over more luxurious nongreen products only when they imagine shopping in public (but not in private). When it comes to social visibility of prosocial acts in general (e.g., conservation, cooperation and charity) people appear to be particularly sensitive to it (Bateson, Nettle, \& Roberts, 2006; Brick, Sherman, \& Kim, 2017). In the public goods game, for instance, it has been shown that people are prone to give money to preserve the environment only when the giving is public and can influence one's reputation (Milinski, Semmann, Krambeck, \& Marotzke, 2006). To conclude, because in the public choice situation people have an opportunity to signal about their prosocial tendencies and considerable resources to others, we hypothesize as follows:

H2. When the choice situation is socially visible, activating the status motives further increases the likelihood of preferring organic foods (compared to a private situation).

\subsection{Senso-emotional experience of organic foods}

Although previous studies have not tackled the effects of activation of nonconscious consumption motive on consumers' senso-emotional food experience - traditional hedonic liking and experiencing more specific taste emotions - there are no reasons to assume that the "going green to be seen" effect would be limited to product choices. Exposure to well-known brands (cf. organic food), for instance, can work as a prime cue leading to goal-directed behavior (Fitzsimons et al., 2008). In the beverage context, it has been shown that after consuming a can of placebo energy drink, blood pressure increased significantly among the study participants with high performance motivation, but not among those with low performance motivation (Irmak, Block, \& Fitzsimons, 2005).

Why, then, would status motives create an improved sensory level experience? To shed light on this issue, we turn our focus to consumer value - brand symbolism (in)congruity explanation model (see Allen et al., 2008). It starts from the premise that products and brands (cf. organic food) possess symbolic contents to which consumers are likely to react on the 
basis of some value - personal values are closely related to basic human motivations (see Grunert, Hieke, \& Wills, 2014). Self-congruity theory (Sirgy, 1982) suggests - the most relevant conceptual idea behind the thinking - that consumers prefer and choose products or brands with symbolic meanings that are congruent with their self-concepts. Incongruity, in turn, usually leads to an opposite effect. For the present study, the particularly relevant insight is that (in)congruity between food brands' symbolic meanings and ones' values can manifest itself in the (un)pleasantness of the taste experience (Allen et al., 2008; Pohjanheimo, Paasovaara, Luomala, \& Sandell, 2010).

The study of Paasovaara et al. (2012) provides an illustrative example of the (in)congruity effects: it discovered that after priming a hedonistic value, the sensory perception of a yogurt brand carrying congruent symbolism was significantly elevated among consumers appreciating hedonism - this effect did not materialize when they tasted a yogurt brand signaling incongruent symbolism (i.e., conservatism).

In a similar way, we postulate that the (in)congruity effect can shape the sensoemotional experience of organic food. Specifically, the activation of consumers' status motive is assumed to trigger their need to be respected and honored amongst the fellow peers. Consequently, the improvement of senso-emotional experience requires that organic foods emit symbolism congruent with this motive. We have contended throughout the manuscript that favoring them is associated with plenty of status-matching symbolism including socially highly-valued features of prosociality and affluence. On the other hand, also incongruity (e.g., the motivational conflict between self-enhancement and self-transcendence drivers - cf. Schwartz, 2010) can emerge - causing a less pleasant senso-emotional food experience. In any case, the (in)congruity theorization supports our rationale.

Senso-emotional experience, including more specific taste emotions, refers to a broader food experience that goes beyond general hedonic liking. The concept was introduced by Thomson (2007). Although sensory food research has traditionally relied on hedonic evaluation when producing understanding about consumers' food product experiences (Lawless \& Heymann, 2010), broader views, going beyond liking, have recently gained more momentum (Gutjar et al., 2015; Ng, Chay, \& Hort, 2013; Schouteten et al., 2017); a major focus has been in emotional conceptualizations (Jiang, King, \& Prinyawiwatkul, 2014; Köster \& Mojet, 2015; Thomson \& Crocker, 2015). This focus is not surprising per se because the interplay between the sensory properties of food and emotions is well-known. A sweet taste, for instance, can create positive emotions, whereas a bitter taste can evoke negative ones (Bagozzi, Gopinath, \& Nyer, 1999); salty and sour, in turn, may elicit various emotional associations, such as surprise, sadness and fear (Rousmans, Robin, Dittmar, \& Vernet-Maury, 2000).

The study of Thomson, Crocker, and Marketo (2010) illustrates well these complex conceptualizations, analyzing the relationships between the sensory characteristics of chocolates and emotions during tasting the products. In the study, one dark chocolate brand characterized by its sweet and creamy flavor yielded emotional associations such as fun, easygoing and comforting, while another dark chocolate brand with a bitter and coffee-like flavor was related to confidence, adventurousness and masculinity. In other words, tasting the food created specific "taste emotions" in the consumers' minds. We adopt this broader food experience view (including general liking and more specific taste emotions) for this paper.

Finally, it must be stressed that organic label (or other corresponding information) is known to have an impact on taste evaluation of food (see Bauer, Heinrich, \& Schäfer, 2013; Bernard \& Liu, 2017; Ellison et al., 2016). In the case of most food categories or types (vegetables, fresh foods, wines etc.) this so called "organic halo effect" is shown to be positive (i.e., higher pleasantness ratings), but some exceptions exist. Organic vice foods, such as sodas and cookies, are typically experienced as less tasty than their conventionally 
produced alternatives (Lee et al., 2013; Van Doorn \& Verhoef, 2011). When tasting blind, however, consumers usually cannot say whether the food sample is produced using organic or conventional methods (e.g., Hughner et al., 2007).

To conclude, since tasting can create a broader food experience and because it is possible that activating a nonconscious goal may affect consumers' sensory food reactions symbolism representing organic food, congruent with prosocial status considerations, heightens this possibility - we hypothesize as follows:

H3. Activating consumers' status motives will improve the senso-emotional experience of organic food and making the reputational aspects salient will further boost it.

In Fig. 1 we summarize the conceptual thinking of the study. Status motive activation not only increases preferring organic food, but also improves its senso-emotional experience. A socially visible choice and tasting situation boosts both of these prosocial status-signaling effects.

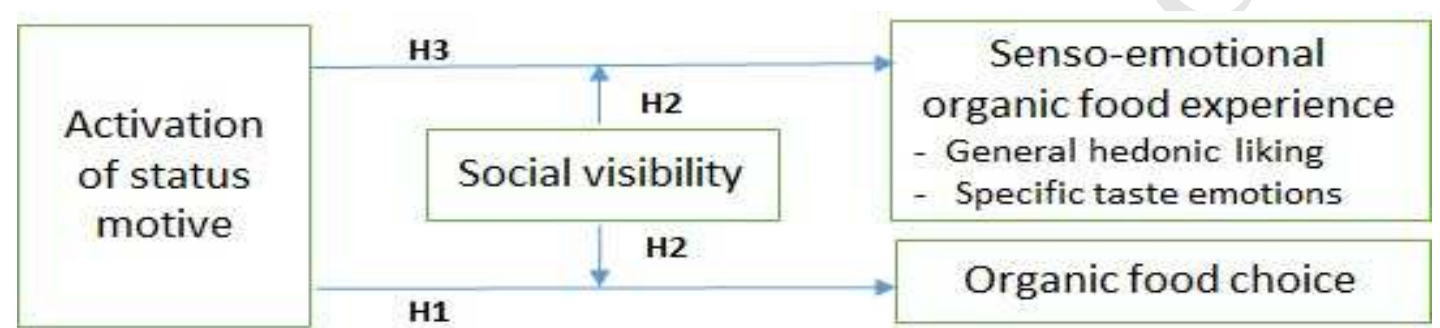

Fig. 1. Hypothesized effects of status motive activation and social visibility on choice and senso-emotional experience of organic food.

\section{Experiment 1}

\subsection{Materials and method}

The first study examined how activating a motive for status influences choices between proenvironmental organic food products and their nonorganic counterparts. As the current research suggests that there may be important links between displays of caring, environmental behaviors, and competition for status, we predicted that activating status motives should increase the likelihood of choosing more organic food products.

Participants, design and procedure: Eighty student consumers $\left(\mathrm{M}_{\mathrm{age}}=26.1\right.$ years, $\mathrm{SD}=3.83,50 \%$ of men, the most common (55\%) household yearly income level 0-19999€), were approached with a questionnaire under the pretext of a memory recall task in a university library in a large Finnish city. First, they were escorted to a peaceful place where they completed the questionnaire (anonymously) at their own pace (approx. 15-20 minutes). The study had two between-subjects motive conditions: status $(n=40)$ and control $(n=40)$, in which the participants were selected randomly. No incentives for participation were given. The study participants were debriefed at the end of the experiment.

Status motives were elicited by showing participants a list of 20 words (on the first page), of which they should remember as many as possible; they were told that they would be asked about the words again at the end of the study (cf. Maio, Pakizeh, Cheung, \& Rees, 2009). Among these nouns were embedded 12 words related to high status (luxury product, designer watch, first class, etc.). The participants had three minutes to look at the words (data collectors ensured that they looked at the words during the time allotted). The control condition was otherwise identical, but this time the noun list included only words without any 
kind of link to high status (backpack, table lamp, fraction, etc.). The participants in this condition also had to look at the words for three minutes. The status words had nothing to do with prosocial behavioral strategies, such as cooperation, helping, self-sacrifice or proenvironmental behavior.

Products: After the motive activation, and before the participants were allowed to make the product choices (approx. $6 \mathrm{~cm}$ x $9 \mathrm{~cm}$ images in color were used), they answered filler questions relating to use of technology. In this way, it was ensured that the participants would not understand the actual purpose of the study (post-study interviews did not reveal any suspiciousness). After these questions, the participants had to make dichotomous choices concerning six food product pairs: two product pairs contained an organic option (bacon \& coffee). These product types were chosen for the study because they are both currently available in an organic and a conventional form - manufactured by the same company - and their package solutions were very similar. Counterbalanced product pairs (i.e., order of the two products varied) were always presented on their own pages. Price information was not shown at any time.

Regarding the other product pairs, in two pairs participants had to make a choice between a more luxurious product and its conventional version (cold cuts and blue cheese). This juxtaposition was included in the study for two reasons. First, we wanted to investigate whether activating a motive for status - in line with traditional status-signaling perspectives would lead consumers to favor more luxurious and indulgent products over conventional ones (cf. Rucker \& Galinsky, 2008). Second, we wanted to have some initial confirmation that status activation would not simply lead people to favor options that are more special, fashionable or unique (cf. organic, luxurious vs. conventional) regardless of the actual product characteristics. Two more pairs (milk and cooking cream) were added as filler products to reduce the possibility that the participants would figure out that organic food products are the key interest of the study.

Pre-tests: We predicted that status motives should lead people to want to be seen as more prosocial, and thus it was important that both organic products were perceived as being associated with more prosociality than their nonorganic counterparts. We thus pretested the perceptions of both products with a separate group of 176 participants ( 88 men, 88 women). These participants saw either the organic products or the nonorganic products. For both of the products, participants indicated on a 1-9 scale the extent to which the person who favors this product was (a) nice, (b) caring, and (c) altruistic. As expected, compared to the nonorganic products, both organic products were associated with being nicer (Ms 5.94, $\mathrm{SD}=1.06$ vs. 5.21, $\mathrm{SD}=1.02, \mathrm{p}<.001, \mathrm{~d}=.7$ ), more caring (Ms 6.40, $\mathrm{SD}=1.14$ vs. 4.41, $\mathrm{SD}=.95, \mathrm{p}<.001, \mathrm{~d}=1.9$ ), and more altruistic (Ms 5.73, $\mathrm{SD}=1.11$ vs. 5.05, $\mathrm{SD}=.99 \mathrm{p}<.01, \mathrm{~d}=.65)$. Thus, as expected, people who seemed to favor these organic products, relative to their nonorganic counterparts, were perceived as more prosocial.

It was also important to verify that the status word list (relative to the control word list) is capable to elicit desire for status. Thus another manipulation check was conducted with a separate group of 30 participants (15 men, 15 women). We used "status consumption statements" developed and validated by Eastman, Goldman, and Flynn (1999). Specifically, after looking at the words and answering the filler questions, participants were asked to indicate on a scale 1-7 the extent they: 1) "are interested in new foods with status", 2) "would buy a food product just because it has status", and 3) "would pay more for a food product if it had status". As expected, the statements (one composite measure was formed, $\alpha=-.747$ ) received higher scores (Ms 3.56, $\mathrm{SD}=.783$ vs. $2.73 \mathrm{SD}=.768, \mathrm{p}<.01, \mathrm{~d}=1.1$ ) among participants who memorized the list of status words $(n=15)$ - participants' sex did not interact with motive primes ( $p>.3$ ) meaning that the word lists had similar effect to men and women. 
Hence, our status prime (compared to control prime) seems to be capable of activating consumers' desire for status.

\subsection{Results and discussion}

The key prediction in the experiment was that activating status motives should increase the likelihood of choosing the organic product (relative) to the same organic product in the control condition. Indeed, as predicted, whereas $50 \%$ of the chosen products were organic in the control condition, the corresponding share was $70 \%$ in the status condition. As interaction was not detected, $\mathrm{p}>.2$, the two target measures were summed to yield a choice index (range: 0-2 - cf. Wheeler \& Berger, 2007). A one-way analysis of variance (ANOVA) showed that this difference is significant $\mathrm{F}(1,78)=5.725, \mathrm{p}=.019, \mathrm{~d}=.53^{2}$. Thus, eliciting status motives may be an effective strategy for promoting sustainable consumption behavior also in the everyday food choice context.

However, when signaling about status, it is not meaningless whether the signaling occurs - be it through seemingly prosocial acts or material possessions - in a private or public setting; in a situation visible to others, the reputational aspects are much more salient (see Wang \& Wallendorf, 2006). Thus, we investigate next how the social visibility of the choice affects organic food preferences.

\section{Experiment 2}

\subsection{Materials and method}

The first study showed that activating status motives increased the tendency to choose a prosocial organic product over a nonorganic product. The second study examined how status motives influenced preferences for organic versus nonorganic products when people considered shopping in a public setting (at a grocery store with a friend). As people appear to be sensitive to the social visibility of prosocial acts, we predicted that when people considered shopping in public (unlike in experiment 1), status motives should further increase preferences for organic foods over nonorganic foods.

Participants, design and procedure: Eighty-eight student consumers $\left(\mathrm{M}_{\mathrm{age}}=28.3\right.$ years, $\mathrm{SD}=4.92,50 \%$ of men, the most common (57\%) household yearly income level 0-19999€) were approached with a questionnaire in a university library in a large Finnish city (approx. two months after the first experiment with a different set of participants). The study design was identical to that of experiment 1 (status condition $n=44$, control condition $n=44$ ). However, this time the choice situation was described to be visible to others. Whereas in experiment 1 , the participants were just asked to choose between the alternatives (i.e., private setting), now they were first instructed to imagine that they are in a store shopping for ingredients for a special dinner with a friend. The post-study interviews did not reveal any suspiciousness this time either. No personal information was collected and afterwards the participants were debriefed.

\subsection{Results and discussion}

\footnotetext{
${ }^{2}$ In terms of the more luxurious vs. conventional product pair (one choice index was formed, $\mathrm{p}>.4$ ), no differences in choices were detected $\mathrm{F}(1,78)=.000, \mathrm{p}=1, \mathrm{~d}=.0$. Thus, status motives did not lead to favor more indulgent food options. This result brings support for ruling out the possibility that organic options are preferred more (after status activation) as they are just "unconventional". It must be highlighted that none of the demographic (sex, age), socio-economic (income level) or situational (activity level and mood) factors asked or the participants' product type or brand attitudes had any effect on DVs (all p-values >.2).
} 
We first pooled the data sets from experiments 1 and 2 together (recall that the measured variables were exactly the same). Then, to examine if status motives had a different effect on preferences depending on whether study participants were choosing in public or private, a two-way ANOVA with motive (status vs. control) and audience (private vs. public) was performed. As the effects of motive and audience did not vary between the products, $\mathrm{p}>.3$, the two target measures were again summed to yield a choice index (range: 0-2). This analysis revealed an indication of interaction $\mathrm{F}(1,164)=3.503, \mathrm{p}=.063, \eta^{2}=.021^{3}$. Specific simple effects were examined next.

As can be seen from Fig. 2, the results are - at first glance - somewhat unexpected (only average percentages are reported). Contrary to the prediction, activating status motives did not further increase preference for organic foods when choosing in public: public status vs. public control $\mathrm{F}(1,164)=.077, \mathrm{p}=.782$, $\mathrm{d}=.05$; public status vs. private status $\mathrm{F}(1,164)$ $=.236, \mathrm{p}=.628, \mathrm{~d}=.1$. On the other hand, analyses revealed an interesting detail, namely, the social visibility of the choice in itself (i.e., public control vs. private control) significantly increased preference for organic foods $F(1,164)=4.668, p=.033, d=.47$. Thus, in the organic food context, the social visibility of the choice seems to act in the same way as priming status motives does. This claim is supported by the fact that in both of the public conditions (status and control) and in the private status condition (i.e., in conditions with reputational concerns), organic foods are equally preferred and this preference was distinctly stronger than in the private control condition (i.e., the only condition devoid of any manipulations).

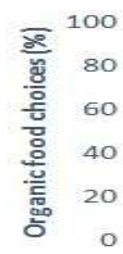

o

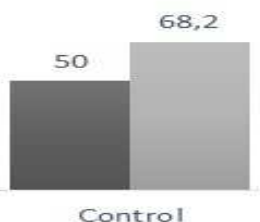

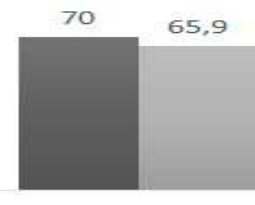

Status
- Private

Public

Fig. 2. Preference for organic foods as a function of primed motive and social visibility of choice.

To conclude, also in this everyday food choice context consumers seem to go green to be seen. The results are in line with the costly signaling theory: the participants preferred prosocial organic foods only when their status motives were activated (experiment 1 ) or when their choices were salient to others (experiment 2) and thus influenced one's reputation.

Hence, we go next beyond product choices and investigate whether the prosocial statussignaling effect also manifests itself in the senso-emotional experience of organic foods. This idea is not conflict with the key tenets of the costly signaling view. Just like preferring a product in a choice, preferring a product in a taste test - especially in a situation visible to others - offers an opportunity to (nonconscious) status signaling.

\section{Experiment 3}

\subsection{Materials and method}

\footnotetext{
${ }^{3}$ A corresponding two-way ANOVA was performed in relation to more luxurious vs. conventional product choices (again, a choice index was formed, $\mathrm{p}>.5$ ); this analysis did not reveal an interaction $\mathrm{F}(1,164)=.012$, $\mathrm{p}=.912, \eta^{2}=.0$. None of the asked control variables (see footnote 2 ) had any effect on DVs this time either (all $\mathrm{p}$ values $>.2$ ).
} 
Experiment 1 showed that activating status motives increased the tendency to choose an organic over a nonorganic food product. Experiment 2 uncovered that making the choice situation visible to others created the same effect. Experiment 3 sought an answer to the question: does the "going green to be seen" effect also manifest itself in the senso-emotional experience of organic food? In line with two previous predictions, we expected that activating consumers' status motives will improve the senso-emotional experience of organic food and that making the reputational aspects salient will further boost it.

Participants and procedure: Two hundred and fifty-seven student consumers were recruited for the study in the university campus area of a large Finnish city $\left(\mathrm{M}_{\mathrm{age}}=25.0\right.$ years, $\mathrm{SD}=3.52,45 \%$ of men, the most common (58\%) household yearly income level 0-19999€). Individuals moving around the campus buildings were approached and asked to participate in a memory recall study which also involves tasting a food samples. As a cover story, we told our study participants that we are interested in how cognitively taxing efforts influence the ability to remember things. To amplify the cover story, we led them to believe that in their group the cognitively taxing efforts related to taking a stand on various statements about their consumption habits, while in the other groups they related to mathematical reasoning and word puzzle-solving.

The consenting individuals were then escorted to a peaceful classroom furnished with a few three-walled cubicles to ensure distraction-free circumstances for tasting the food samples and completing the questionnaire (approx. 20-25 minutes). Social visibility was manipulated by leading the study participants at the public condition $(n=137)$ to believe that they were supposed to share their food responses with the researchers at the end of the experiment (this instruction was given both orally and via text in the questionnaire). At the private condition $(n=120)$, no such instructions were voiced. According to the post-study interviews, participants did not see the connection between the memorization task and taste test. They received a canteen voucher worth six euros for their time and effort. No personal information was collected and afterwards the participants were thanked and debriefed.

Design and measurement of senso-emotional experience of food: The study had a 2 (audience: public vs. private) x 2 (motive: status vs. control) x 2 (informed production method: organic vs. conventional) between-subjects design. Study participants were randomly assigned to each of the experimental conditions. Status motives were primed in the same way as in experiments 1 and 2. Likewise, the questionnaire remained essentially unchanged; only the section concerning the measurement of DV was revised. The senso-emotional experience of food was gauged, first by the conventional hedonic liking item (taste un/pleasantness, scale 1-7) and second by measuring the emotions the taste elicited (cf. Spinelli, Masi, Dinnella, Zoboli, \& Monteleone, 2014). These included both positive-negative and private-collective emotions (scale 1-7): joy, hopefulness, irritation and disappointment (cf. Luomala, Sirieix, \& Tahir, 2009; Onwezen, 2015). Finally, participants were requested to indicate the intensity of their purchase intention toward the foods they tasted (scale 1-7).

Food samples: Each study participant's senso-emotional experience was recorded for two food product samples: carrot (in grated form) and cheese (as chunks). The samples were prepared following the same procedures on the day before the experiment and stored in the refrigerator $\left(5^{\circ} \mathrm{C}\right)$ in sealable containers. Before the actual taste tests, the samples were kept at room temperature for one to two hours. Carrot was selected as the focal food sample as it is a simple agricultural product devoid of complex extra symbolism. One group of participants was informed (in the questionnaire) that they would taste grated carrots that were conventionally produced and another that they were grown organically.

In turn, cheese was chosen as the second taste sample because it represents a more refined product category with a wider range of market offerings and is thus imbued with 
symbolic meanings (cf. Vieitez, Gámbaro, Callejas, Miraballes, \& Irigaray, 2014). This time, one group of participants were led to believe that they would taste "ordinary" cheese, while another group was told that the cheese was "luxurious" (cf. Jacquot, Berthaud, Sghaïr, Diep, \& Brand, 2013). In effect, the inclusion of cheese measurements served to 1) investigate whether status activation improves the senso-emotional experience of a "luxurious food" (cf. cold cuts and blue cheeses in experiment 1) and 2) mask the fact that the study is interested in the effect of the "organic" cue. In reality, the food samples were always prepared using the same food product material.

\subsection{Results and discussion}

To examine if the status motive activation and visibility of the food responses had a different effect on the senso-emotional experience of a food sample that the participants were told was conventionally vs. organically produced (DVs: taste, joy, hopefulness, disappointment, irritability and purchase intention), a three-way ANOVA with the motive (status vs. control), informed production method (organic vs. conventional) and audience (private vs. public) as IVs was performed. This analysis revealed an indication of interaction in relation to taste $\mathrm{F}(1,249)=3.542, \mathrm{p}=.061, \eta^{2}=.014$, joy $\mathrm{F}(1,249)=3.594, \mathrm{p}=.059, \eta^{2}=.014$, hopefulness $\mathrm{F}(1,249)=10.943, \mathrm{p}=.001, \eta^{2}=.042$ and purchase intention $\mathrm{F}(1,249)=2.689$, $\mathrm{p}=.102, \eta^{2}=.011$ but not in relation to disappointment $\mathrm{F}(1,249)=.004, \mathrm{p}=.951, \eta^{2}=.0$ and irritability $\mathrm{F}(1,249)=.337, \mathrm{p}=.562, \eta^{2}=.001^{4}$. Specific simple effects were examined next.

As can be seen from Fig. 3, activating status motives (vs. control motives) did not improve the senso-emotional experience of a food sample believed to be organic in the private condition. Yet, the food sample served as organic received slightly higher taste $\left(\mathrm{M}_{\text {status prime }}\right.$ $\left.=5.7, \mathrm{SD}=.915 ; \mathrm{M}_{\text {control prime }}=5.51, \mathrm{SD}=.820 ; \mathrm{F}(1,249)=.647, \mathrm{p}=.422, \mathrm{~d}=.22\right)$, joy $\left(\mathrm{M}_{\text {status prime }}\right.$ $\left.=4.33, \mathrm{SD}=1.348 ; \mathrm{M}_{\text {control prime }}=4.3, \mathrm{SD}=1.368 ; \mathrm{F}(1,249)=.008, \mathrm{p}=.929, \mathrm{~d}=.02\right)$, hopefulness $\left(\mathrm{M}_{\text {status prime }}=4.23, \mathrm{SD}=1.371 ; \mathrm{M}_{\text {control prime }}=4.1, \mathrm{SD}=1.768 ; \mathrm{F}(1,249)=.115, \mathrm{p}=.734, \mathrm{~d}=.08\right)$ and purchase intention $\left(\mathrm{M}_{\text {status prime }}=4.37, \mathrm{SD}=1.520 ; \mathrm{M}_{\text {control prime }}=3.97, \mathrm{SD}=1.351\right.$; $\mathrm{F}(1,249)=1.092, \mathrm{p}=.297, \mathrm{~d}=.28)$ ratings.

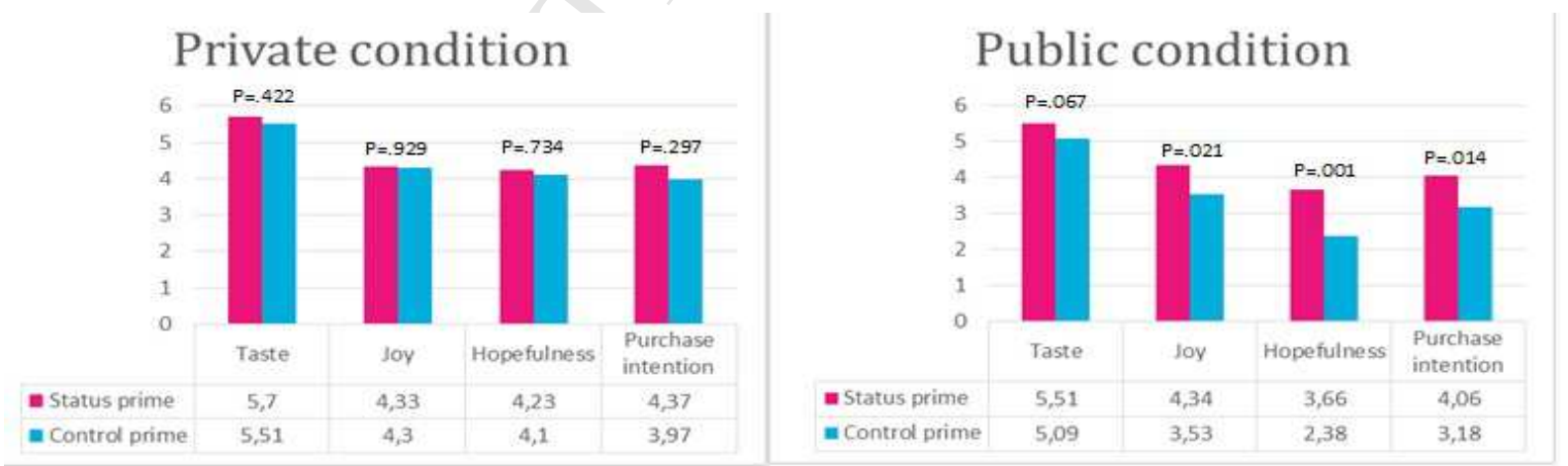

Fig. 3. Senso-emotional experience of food samples believed to be organic in different experimental conditions.

Regarding our follow-up prediction (i.e., that making the tasting situation visible to others should improve the senso-emotional experience), the analyses revealed that this was indeed the case (see Fig. 3). When status motives were activated (vs. control motives) in the

\footnotetext{
${ }^{4}$ A corresponding three-way ANOVA was performed in relation to cheese sample experiences (motive, cheese information and audience); this analysis did not reveal indications of interaction in terms of any DV (p-values ranging from .411 to .821$)$. Hence, specific simple effects were not examined.
} 
public condition, the food sample served as organic not only tasted (marginal effect) more pleasant $\left(\mathrm{M}_{\text {status prime }}=5.51, \mathrm{SD}=.742 ; \mathrm{M}_{\text {control prime }}=5.09, \mathrm{SD}=1.138 ; \mathrm{F}(1,249)=3.376\right.$, $\mathrm{p}=.067, \mathrm{~d}=.44)$, but also created more intense emotions of joy $\left(\mathrm{M}_{\text {status prime }}=4.34, \mathrm{SD}=1.571\right.$; $\left.\mathrm{M}_{\text {control prime }}=3.53, \mathrm{SD}=1.522 ; \mathrm{F}(1,249)=5.432, \mathrm{p}=.021, \mathrm{~d}=.52\right)$ and hopefulness $\left(\mathrm{M}_{\text {status prime }}\right.$ $\left.=3.66, \mathrm{SD}=1.878 ; \mathrm{M}_{\text {control prime }}=2.38, \mathrm{SD}=1.415 ; \mathrm{F}(1,249)=12.138, \mathrm{p}=.001, \mathrm{~d}=.77\right)$ and even stronger purchase intention $\left(\mathrm{M}_{\text {status prime }}=4.06, \mathrm{SD}=1.626 ; \mathrm{M}_{\text {control prime }}=3.18, \mathrm{SD}=1.732\right.$; $\mathrm{F}(1,249)=6.084, \mathrm{p}=.014, \mathrm{~d}=.52)$. Thus, it seems that the "going green to be seen" effect is not limited to product choices, but extends to the more physiologically-driven senso-emotional experience of food ${ }^{5}$. In other words, the effects of motivational priming can go beyond the well-established evaluative and behavioral domains. As for the other simple effects, no significant differences were found.

In summary, three novel insights emerge from this research. First, activating consumers' status motives increases the likelihood of prosocial status signaling through organic food choices. Second, making the reputational aspects of choice salient (i.e., visible to others) also heightens its probability. Third, activating consumers' status motives and simultaneously making the reputational aspects of tasting salient (i.e., visible to others) creates an improved senso-emotional experience of organic foods.

\section{Conclusion and implications}

From the outset, one might think that everyday food choices and sending reputational messages are poorly compatible with each another. By applying insights from the costly signaling theory, we have proven otherwise in this paper (through three experiments). When consumers' status motives were activated, they made significantly more prosocial organic food choices in this smaller price tag context (experiment 1); it was not even necessary to activate status motives, as just making the reputational aspects salient sufficed to create the same effect (experiment 2). These findings strongly indicate that food consumers go green for reputational reasons. However, this was not the whole story. We demonstrated that in addition to product choices, the "going green to be seen" effect can manifest itself in the sensoemotional experience of organic food (experiment 3). Next, the theoretical and practical implications of the findings together with study limitations and future research suggestions are discussed in more detail.

\subsection{Theoretical implications}

The fact that prosocial status signaling, the "going green to be seen" effect, can manifest itself at the level of senso-emotional food responses represents novel understanding - when reputation was at stake, even the taste experience became more pleasant. Why did signaling make study participants happy and hopeful? One might think that the "better taste" of organically produced food made them feel happy. Another, quite intuitive explanation might be that favoring a prosocial alternative puts one in a good mood because one is behaving in a way that is beneficial for other people, society and even the planet. However, differences emerged when tasting the same product, which was always presumably organically produced. Activating the status motives can explain these findings to a certain extent. However, participants experienced positive emotions only in the public condition. We suggest that happiness is experienced (nonconsciously) when one has the opportunity to attain status and to climb up in the peer group hierarchy - higher pleasantness ratings open up the possibility to signal about one's prosocial tendencies.

\footnotetext{
${ }^{5}$ As in the case of previous experiments, none of the asked demographic, socio-economic or situational factors (see footnote 2) nor product type attitudes had any effect on DVs (all p-values >.2).
} 
Another relevant question is: why did social visibility have a slightly different effect in the product choice and tasting experiments? This might be due to the fact that the manipulation method was not the same. Whereas the witness of the signaling was a fictional friend (familiar) in experiment 2, this was an actual person (a previously unfamiliar researcher) in experiment 3. Studies conducted in the social facilitation domain often suggests that the impact of audience on actors' behavior can expected to be stronger - due to a sense of uncertainty - if the actor is unfamiliar with the audience (see Guerin, 2010). Furthermore, it is known that the witness's status can moderate the audience effect; people tend to become more cautious in front of an audience with a higher status (cf. Anderson, Hildreth, \& Howland, 2015). Accordingly, we can speculate that perhaps social pressure created by the presence of a presumably smart academician - above the student in the hierarchy - is more intense than the corresponding pressure created by a friend. This claim receives support from the fact that in the public condition (experiment 3) the ratings are generally lower than in the private condition.

Conceptually the intensity could mean - as the participants knew they are being judged - that evaluation apprehension (see Baumeister, Ainsworth, \& Vohs, 2016; Feinberg \& Aiello, 2006) has been present in experiment 3. In practice, when the signaling had a witness (researcher), but when the desire for status had not been activated (control prime), participants became cautious in their judgments (due to the potential for immediate reputation harms). When the desire for status was activated in the presence of a witness, this concern vanished (as a result of nonconscious status activation, the motivational focus possibly shifted from avoiding reputation harms to attaining potential reputation benefits). This mediating mechanism of social facilitation (see Uziel, 2007) could explain the substantial differences in evaluations between the motive primes in the public setting (see Fig. 3). In any case, the results speak the high importance of controlling the meanings attached to the method when manipulating social visibility. Yet, prosocial status signaling occurring through favoring organic foods - possibly because of the expected reputation benefits - seems to have the power to make consumers happy.

Consumer research has recently produced startling findings concerning the effects of motivational priming on consumers' behavior and choices (e.g., Janiszevski \& Wyer, 2014; Madzharov, Block, \& Morrin, 2015; Nenkov \& Scott, 2014; Park \& John, 2014). In the food realm, exposing study participants to a power prime leads them to signal their status through choice of food portion size (Dubois et al., 2012). In a similar way, a promotion prime led to an increase in food portion size behavior, whereas a prevention prime caused a decrease in the same behavior (Webster, Chakrabarty, \& Kinard, 2016). In the case of healthiness, a gratefulness prime (vs. pride) created more unhealthy choices (Schloesser, 2015), while putting health-related cues (vs. pleasure-related ones) at vending machines promoted healthier choices (Stöckli et al., 2016). Some consumers may even become promotion-oriented when their motivations are primed by a hedonically tempting food and this type of priming then guides their subsequent hedonic food consumption (Sengupta \& Zhou, 2007). However, no evidence can be found of any effects of motivational priming on consumers' senso-emotional food experience. Hence, our findings from consumers' nonconscious food responses - that go beyond the well-established evaluative and behavioral domains - provide an extension to the literature of motivational priming.

Although some indications of the reputational value of organic foods have been found (Carfagna et al., 2014; Cervellon \& Shammas, 2013; Costa, Zepeda, \& Sirieix, 2014; Kniazeva \& Venkatesh, 2007), the findings have been more or less ambiguous; these mundanely consumed products are said to be shopped for as effortlessly as their conventionally produced alternatives (Thøgersen et al., 2012). Furthermore, many consumers do not appreciate organic production methods (Bellows, Alcaraz, \& Hallman, 2010). 
According to our findings, favoring organic foods indeed possesses status-enhancing potential. In other words, they can be used as one's status-signaling efforts. This raises the question of how big actually is the consumer segment that favors organic foods for other motives - such as reputation management - than the often self-reported and socially approved reasons of healthiness, tastiness and ethical concerns. Future studies are encouraged to take both socially approved and disapproved motives into account at the same time when studying organic food consumption.

Our findings bring support for the idea that favoring organic foods can act as a costly signal of status. Lee et al. (2015) and Nelissen and Meijers (2011) have shown that favoring luxury products can act as such a signal; in the latter study, wearing a high-status brand-name shirt (vs. an unbranded shirt) even created several real-life behavior benefits for this person. Griskevicius et al. (2010) suggested that favoring green consumer durables can act as a costly signal of status. In this paper we have shown, contrary to previous studies, that a behavior strategy as mundane as food consumption can act as a costly signal of status. A lone example suggesting the same is the study of Puska et al. (2016), in which a male who seemed to favor organic foods was not only perceived more positively, but was also favorably treated. In the study of Puska et al. (2016), as in the one of Griskevicius et al. (2010), however, the prosocial signaling effects were investigated in relation to simple behavior intentions and perceptual experiences (cf. more physiologically-driven food responses in the present study).

Finally, it is known that a considerable part of consumers' behavior is nonconscious (see Lee et al., 2013). Some evolutionary-minded researchers have suggested (e.g., Griskevicius \& Kenrick, 2013; Saad, 2016) that all our behaviors are guided by nonconscious, fundamental motives (e.g., desire for status). In the food realm, acknowledging the importance of nonconscious forces is especially relevant since it has been estimated that the majority of food-related decisions occur at a nonconscious, automatic level (Cohen \& Babey, 2012). According to Köster (2009), intuitive reasoning and nonconscious decision making play a more important role in food-related behavior than in probably any other area of consumption. Also in the present study, the "going green to be seen" effect occurred as a result of subtle nonconscious priming. The message of this discussion is that food-related consumer research should primarily utilize methods - in addition to priming - that are capable of tapping into consumers' nonconscious processes and responses (e.g., nudging - see Wilson, Buckley, Buckley, \& Bogomolova, 2016).

\subsection{Study limitations and future research suggestions}

As always, some study limitations can be identified. At the same time, they offer fruitful opportunities for further research.

This study concentrated on how prosocial organic foods are preferred and how they are experienced in terms of senso-emotional properties after (status) motivational priming efforts. Due to the long procedure, only one prosocial food sample was included in the study: a simple agricultural product, carrot in grated form. Thus, it is not possible to take a stand on whether consumers' food responses would have been the same if the served sample had been more processed (e.g., organic dairy product), classifiable as a vice food (see Van Doorn \& Verhoef, 2011) or inherently rich in terms of food symbolism (e.g., organic meat and masculinity - see Schösler, de Boer, Boersema, \& Aiking, 2015 - or organic chocolate and emotionality - see Thomson et al., 2010). In other words, the generalizability of the findings beyond the organic vegetable context is left for future research to (dis)confirm.

Experiments 1 and 2 did not involve actual purchases, but hypothetical product choices (i.e., behavioral intentions). Thus, these findings must be validated with different methods (preferably involving actual purchases), in a more natural setting (preferably in a real retail 
environment) and in other product categories than bacon and coffee, so that a more accurate picture can be formed of to what extent food consumers go green to be seen. Also products with some other prosocial claims, such as local (Denver \& Jensen, 2014; Memery, Angell, Megicks, \& Lindgreen, 2015) or fair trade (Kimura et al., 2012) foods, must be investigated.

In experiment 3, after the motivational priming efforts, the (assumed) organic food sample was experienced rather similarly regardless of the dimension in question (taste, emotions of joy and hopefulness and purchase intention). This raises the question of whether some kind of "halo effect" that we are not aware of is influencing food responses (cf. Chernev \& Blair, 2015). In this case, exposure to status competition triggers a need to stand out in consumers, which in turn is realized in the form of higher general ratings toward the organic food sample. So that a more precise answer to this question can be given also other (more objective) methods should be applied.

Neuroscience provides a potential method to exclude possible "halo effects" and generally to examine food-related nonconscious behavior. The neuromarketing approach (e.g., Plassmann, Ramsøy, \& Milosavljevic, 2012) can provide - by avoiding the bias always present in self-reported evaluations - an additional or completely alternative way to do consumer research; in some cases (more subjective) conventional consumer research and (objective) neuromarketing data can even disagree (see Hammou, Galib, \& Melloul, 2013).

As for the theoretical underpinnings of the present study, it must be noted that the foundations of the costly signaling view partly originate from the evolutionary theory of sexual selection. Even though it has been successfully applied in business research, it may be imperfect for understanding how ethical consumption behaviors such as favoring organic food serve reputation management and coalition formation within social networks devoid of mating concerns. The notions of reciprocal altruism (Kurzban, Burton-Chellew, \& West, 2015) and indirect reciprocity ( $\mathrm{Wu}$, Balliet, \& Van Lange, 2016) provide alternative promising conceptualizations for tackling these phenomena.

The fact cannot be ignored that the experiments were conducted in a nationally large city and in a university campus area. That is to say, the study participants were highly educated (or enrolled in university) and the vast majority of them were from urban areas. The study of Puska et al. (2016) revealed that even within the same, highly developed and homogenous Western country, there may be great variations in terms of how prosocial status signaling or organic foods are viewed. Thus, before generalizing the findings, the experiments should be replicated in a socio-culturally distinct area (e.g., rural areas) and among other participants than university graduates (e.g., blue-collar workers).

The fact that no direct information was collected on participants' associations regarding organic food or their own purchase frequencies can be viewed as a limitation of the present study. Another limitation is that, unlike in the case of organic food, we did not pretest to what extent the more indulgent food products (cold cuts and blue cheese in experiment $1 \& 2$ ) or cheese sample served as "luxurious" (in experiment 3) were actually perceived to represent more indulgent or luxurious food options. On the other hand, effects relating to these foods were not the primary interest of the research.

Possible moderators of the "going green to be seen" effect cannot be ignored. In terms of traditional demographic (sex, age) or socio-economic factors (income level), no moderation was detected, but are there others? One potential moderator is consumers' personal values (see Caracciolo et al., 2016). Driving a Prius, for example, confers greater benefit in communities with strong environmental values than in other communities (Sexton \& Sexton, 2014). Thus, an interesting question is whether consumers who lean toward self-enhancement values (power, achievement) are more inclined to prefer organic foods when exposed to status competition than those who lean toward conservation (security, conformity, tradition) or selftranscendence (benevolence, universalism) values. In addition to personal values, other 
psychological characteristics should not be overlooked. Narcissism, for instance, can qualify as a possible moderator. According to Naderi and Strutton (2015), narcissists are inclined to buy more expensive green products due to the prestigious and luxurious image they confer to others.

\subsection{Practical implications}

After the motivational priming efforts, the participants not only had a greater preference for organic food products (experiments $1 \& 2$ ), but also a stronger intention to purchase them (experiment 3). To illustrate the managerial potential of this finding, it is well known that, due to their high price, consumers do not purchase organic foods more often even though the selfreported attitudes toward them are usually rather positive (see Marian et al., 2014). Thus, in spite of the high price, making the reputational aspects more salient in their sales environments (e.g., clues capable of activating consumers' status motives and more visible selling locations) might be an effective way to boost their sale (cf. Rana \& Paul, 2017). More generally, eliciting reputational concerns may be an effective strategy for promoting sustainable consumption behavior (cf. Noppers, Keizer, Bolderdijk, \& Steg, 2014).

The previous research has shown that arousal of (especially) positive emotions is a significant determinant of prosocial (including proenvironmental) behaviors (e.g., BissingOlson et al., 2013; Russell \& Friedrich, 2015). In the present study, after tasting the assumed organic food sample, status-primed participants experienced more intense (positive) emotions of joy and hopefulness, while tasting had no effect on (negative) emotions of irritation and disappointment. Thus, eliciting positive emotions may have some efficacy when encouraging consumers to make more organic food choices. Creative marketers can implement this in practice by creating package solutions for organic food products capable of activating especially positive emotions - utilization of emojis and emoticons might be one way (see Vidal, Ares, \& Jaeger, 2016).

\section{Funding}

This work was supported by the Academy of Finland [grant number 259478]; and the Foundation for Economic Education [grant number 5-3257].

\section{References}

Allen, M., W., Gupta, R., \& Monnier, A. (2008). The interactive effect of cultural symbols and human values on taste perception. Journal of Consumer Research, 35(2), 294-308.

Anderson, C., Hildreth, J. A. D., \& Howland, L. (2015). Is the desire for status a fundamental human motive? A review of the empirical literature. Psychological Bulletin, 141(3), 574-601.

Ariely, D., Bracha, A., \& Meier, S. (2009). Doing good or doing well? Image motivation and monetary incentives in behaving prosocially. American Economic Review, 99(1), 544555.

Aschemann $\square$ Witzel, J., \& Zielke, S. (2017). Can't buy me green? A review of consumer perceptions of and behavior toward the price of organic food. Journal of Consumer Affairs, 51(1), 211-251.

Baumeister, R. F., Ainsworth, S. E., \& Vohs, K. D. (2016). Are groups more or less than the sum of their members? The moderating role of individual identification. Behavioral and Brain Sciences, 39, 1-14, 
Bagozzi, R. P., Gopinath, M., \& Nyer, P. U. (1999). The role of emotions in marketing. Journal of the Academy of Marketing Science, 27(2), 184-206.

Bateson, M., Nettle, D., \& Roberts, G. (2006). Cues of being watched enhance cooperation in a real-world Setting. Biology Letters, 2(3), 412-414.

Bauer, H. H., Heinrich, D., \& Schäfer, D. B. (2013). The effects of organic labels on global, local, and private brands: More hype than substance? Journal of Business Research, 66(8), 1035-1043.

Bellows, A. C., Alcaraz, G., \& Hallman, W. K. (2010). Gender and food, a study of attitudes in the USA towards organic, local, U.S. grown, and GM-free foods. Appetite, 55(3), 540-550.

Bereczkei, T., Birkas, B., \& Kerekes, Z. (2010) Altruism towards strangers in need: Costly signaling in an industrial society. Evolution and Human Behavior, 31(2), 95-103.

Bernard, J. C., \& Liu, Y. (2017). Are beliefs stronger than taste? A field experiment on organic and local apples. Food Quality and Preference, 61, 55-62.

Bissing-Olson, M., Iyer, A., Fielding, K., \& Zacher, H. (2013). Relationships between daily affect and pro-environmental behavior at work: The moderating role of proenvironmental attitude. Journal of Organizational Behavior, 34(1), 156-175.

Bliege Bird, R., \& Smith, E. A. (2005). Signaling theory, strategic interaction, and symbolic capital. Current Anthropology, 46(2), 221-248.

Boizot-Szantai, C., Hamza, O., \& Soler, L. G. (2017). Organic consumption and diet choice: An analysis based on food purchase data in France. Appetite, 117, 17-28.

Brick, C., Sherman, D. K., \& Kim, H. S. (2017). "Green to be seen" and "brown to keep down": Visibility moderates the effect of identity on pro-environmental behavior. Journal of Environmental Psychology, 51, 226-238.

Caracciolo, F., Cicia, G., Del Giudice, T., Cembalo, L., Krystallis, A., \& Grunert, K. G. (2016). Human values and preferences for cleaner livestock production. Journal of Cleaner Production, 112(1), 121-130.

Carfagna, L. B., Dubois, E. A., Fitzmaurice, C., Ouimette, M. Y., Schor, J. B., Willis, M., \& Laidley, T. (2014). An emerging eco-habitus: The reconfiguration of high cultural capital practices among ethical consumers. Journal of Consumer Culture, 14(2), 158178.

Cervellon, M-C., \& Shammas, L. (2013). The value of sustainable luxury in mature markets: A customer-based approach. Journal of Corporate Citizenship, 52, 90-101.

Chernev, A., \& Blair, S. (2015). Doing well by doing good: The benevolent halo of corporate social responsibility. Journal of Consumer Research, 41(6), 1412-1425.

Cohen, D. A., \& Babey, S. H. (2012). Contextual influences on eating behaviours: heuristic processing and dietary choices. Obesity Reviews, 13(9), 766-779.

Costa, S., Zepeda, L., \& Sirieix, L (2014). Exploring the social value of organic food: A qualitative study in France. International Journal of Consumer Studies, 38(3), 228-237.

Delgado, M. S., Harriger, J. L., \& Khanna, N. (2015). The value of environmental status signaling. Ecological Economics, 111(1), 1-11.

Denver, S., \& Jensen, J. D. (2014). Consumer preferences for organically and locally produced apples. Food Quality and Preference, 31, 129-134.

Dubois, D., Rucker, D. D., \& Galinsky, A. D. (2012). Super size me: Product size as a symbol of status. Journal of Consumer Research, 38(6), 1047-1062.

Eastman, J. K., Goldsmith, R. E., \& Flynn, L. R. (1999). Status consumption in consumer behavior: Scale development and validation. Journal of Marketing Theory and Practice, 7(3), 41-52.

Elliot, R. (2013). The taste for green: The possibilities and dynamics of status differentiation through "green" consumption. Poetics, 41(3), 294-322. 
Ellison, B., Duff, B. R., Wang, Z., \& White, T. B. (2016). Putting the organic label in context: Examining the interactions between the organic label, product type, and retail outlet. Food Quality and Preference, 49, 140-150.

Feinberg, J. M., \& Aiello, J. R. (2006). Social facilitation: A test of competing theories. Journal of applied social psychology, 36(5), 1087-1109.

Fitzsimons, G. M., Chartrand, T. L., \& Fitzsimons, G. J. (2008). Automatic effects of brand exposure on motivated behavior: how apple makes you "think different". Journal of Consumer Research, 35(1), 21-35.

Fotopoulos, C., \& Krystallis, A. (2002). Purchasing motives and profile of the Greek organic consumer: a countrywide survey. British Food Journal, 104(9), 730-765.

Griskevicius, V., \& Kenrick, D. T. (2013). Fundamental motives for why we buy: how evolutionary needs influence consumer behavior. Journal of Consumer Psychology, 23(3), 372-386.

Griskevicius, V., Tybur, J. M., \& Van den Bergh, B. (2010). Going green to be seen: Status, reputation, and conspicuous conservation. Journal of Personality and Social Psychology, 98(3), 392-404.

Grunert, K. G., Hieke, S., \& Wills, J. (2014). Sustainability labels on food products: Consumer motivation, understanding and use. Food Policy, 44, 177-189.

Guerin, B. (2010). Social facilitation. John Wiley \& Sons, Inc.

Gutjar, S., de Graaf, C., Kooijman, V., de Wijk, R. A., Nys, A., Ter Horst, G. J., \& Jager, G. (2015). The role of emotions in food choice and liking. Food Research International, 76, 216-223.

Hammou, K. A., Galib, M. H., \& Melloul, J. (2013). The contributions of neuromarketing in marketing research. Journal of Management Research, 5(4), 20.

Hardy, C. L., \& Van Vugt, M. (2006). Nice guys finish first: The competitive altruism hypothesis. Personality and Social Psychology Bulletin, 32(10), 1402-1413.

Hemmerling, S., Hamm, U., \& Spiller, A. (2015). Consumption behaviour regarding organic food from a marketing perspective - a literature review. Organic Agriculture, 5(4), 277-313.

Hjelmar, U. (2011). Consumers' purchase of organic food products. A matter of convenience and reflexive practices. Appetite, 56(2), 336-344.

Hughner, R. S., McDonagh, P., Prothero, A., Shultz, C. J., \& Stanton, J. (2007). Who are organic food consumers? A compilation and review of why people purchase organic food. Journal of Consumer Behaviour, 6(2 $\square 3)$, 94-110.

IFOAM (2016). Organic in Europe: Prospects and developments 2016. https://shop.fibl.org/fileadmin/documents/shop/1708-organic-europe-2016.pdf Accessed 2 April 2017.

Irmak, C., Block, L. G., \& Fitzsimons, G. J. (2005). The placebo effect in marketing: Sometimes you just have to want it to work. Journal of Marketing Research, 42(4), 406-409.

Jacquot, L., Berthaud, L., Sghaï, A., Diep, C., \& Brand, G. (2013). The influence of "tastiness" and "healthiness" labels in cheese flavor perception. Chemosensory Perception, 6(2), 53-59.

Janiszewski, C., \& Wyer, R. S. (2014). Content and process priming: A review. Journal of Consumer Psychology, 24(1), 96-118.

Jensen, K. D., Denver, S., \& Zanoli, R. (2011). Actual and potential development of consumer demand on the organic food market in Europe. NJAS: Wageningen Journal of Life Sciences, 58(3), 79-84. 
Jiang, Y., King, J. M., \& Prinyawiwatkul, W. (2014). A review of measurement and relationships between food, eating behavior and emotion. Trends in Food Science \& Technology, 36(1), 15-28.

Kareklas, I., Carlson, J. R., \& Muehling, D. D. (2014). 'I eat organic for my benefit and yours': Egoistic and altruistic considerations for purchasing organic food and their implications for advertising strategists. Journal of Advertising, 43(1), 18-32.

Kimura, A., Mukawa, N., Yamamoto, M., Masura, T., Yuasa, M., Goto, S., Oka, T., \& Wada, Y. (2012). The influence of reputational concerns on purchase intention of fair-trade foods among young Japanese adults. Food Quality and Preference, 26(2), 204-210.

Kniazeva, M., \& Venkatesh, A. (2007). Food for thought: A study of food consumption in postmodern US culture. Journal of Consumer Behaviour, 6(6), 419-435.

Kurzban, R., Burton-Chellew, M. N., \& West, S. A. (2015). The evolution of altruism in humans. Annual Review of Psychology, 66, 575-599.

Köster, E. P. (2009). Diversity in the determinants of food choice: A psychological perspective. Food Quality and Preference, 20(2), 70-82.

Köster, E. P., \& Mojet, J. (2015). From mood to food and from food to mood: A psychological perspective on the measurement of food-related emotions in consumer research. Food Research International, 76(2), 180-191.

Lawless, H. T., \& Heymann, H. (2010). Sensory evaluation of food: principles and practices. New York: Springer.

Lee, H. J., \& Hwang, J. (2016). The driving role of consumers' perceived credence attributes in organic food purchase decisions: A comparison of two groups of consumers. Food Quality and Preference, 54, 141-151.

Lee, J., Ko, E., \& Megehee, C. M. (2015). Social benefits of brand logos in presentation of self in cross and same gender influence contexts. Journal of Business Research, 68(6), 1341-1349.

Lee, W. J., Shimizu, M., Kniffin, K. M. \& Wansink, B. (2013). You taste what you see: do organic labels bias taste perceptions? Food Quality and Preference, 29(1), 33-39.

Luomala, H. T., Sirieix, L., \& Tahir, R. (2009). Exploring emotional-eating patterns in different cultures: Toward a conceptual framework model. Journal of International Consumer Marketing, 21(3), 231-245.

Madzharov, A. V., Block, L. G., \& Morrin, M. (2015). The cool scent of power: effects of ambient scent on consumer preferences and choice behavior. Journal of Marketing, 79(1), 83-96.

Magkos, F., Arvaniti, F., \& Zampelas, A. (2006). Organic food: Buying more safety or just peace of mind? A critical review of the literature. Critical Reviews in Food Science and Nutrition, 46(1), 23-56.

Magnusson, M. K., Arvola, A., Hursti, U., Aberg, L., \& Sjoden, P. (2003). Choice of organic food is related to perceived consequences for human health and to environmentally friendly behaviour. Appetite, 40(2), 109-117.

Maio, G. R., Pakizeh, A., Cheung, W. Y., \& Rees, K. J. (2009). Changing, priming, and acting on values: effects via motivational relations in a circular model. Journal of Personality and Social Psychology, 97(4), 699.

Mandel, N., Petrova, P. K., \& Cialdini, R. B. (2006). Images of success and the preference for luxury brands. Journal of Consumer Psychology, 16(1), 57-69.

Marian, L., Chrysochou, P., Krystallis, A., \& Thøgersen, J. (2014). The role of price as a product attribute in the organic food context: An exploration based on actual purchase data. Food Quality and Preference, 37, 52-60. 
Maynard, M. (2007). Say "hybrid" and many people will hear "Prius". The New York Times, July 4. http://www.nytimes.com/2007/07/04/business/04hybrid.html Accessed 2 April 2017.

Memery, J., Angell, R., Megicks, P., \& Lindgreen, A. (2015). Unpicking motives to purchase locally-produced food: Analysis of direct and moderation effects. European Journal of Marketing, 48(7-8), 1207-1233.

Milinski, M., Semmann, D., Krambeck, H-J., \& Marotzke, J. (2006). Stabilizing the earth's climate is not a losing game: Supporting evidence from public goods experiments. Proceedings of the National Academy of Sciences, USA, 103(11), 3994-3998.

Naderi, I., \& Strutton, D. (2015). I support sustainability but only when doing so reflects fabulously on me: Can green narcissists be cultivated? Journal of Macromarketing, 35(1), 70-83.

Nelissen, R. M. A., \& Meijers, M. H. C. (2011). Social benefits of luxury brands as costly signals of wealth and status. Evolution and Human Behavior, 32(5), 343-355.

Nenkov, G. Y., \& Scott, M. L. (2014). "So cute I could eat it up": priming effects of cute products on indulgent consumption. Journal of Consumer Research, 41(2), 326-341.

$\mathrm{Ng}$, M., Chaya, C., \& Hort, J. (2013). The influence of sensory and packaging cues on both liking and emotional, abstract and functional conceptualisations. Food Quality and Preference, 29(2), 146-156.

Noppers, E. H., Keizer, K., Bolderdijk, J. W., \& Steg, L. (2014). The adoption of sustainable innovations: Driven by symbolic and environmental motives. Global Environmental Change, 25, 52-62.

Nuttavuthisit, K., \& Thøgersen, J. (2017). The importance of consumer trust for the emergence of a market for green products: The case of organic food. Journal of Business Ethics, 110(2), 323-337.

Onwezen, M. C. (2015). I did good, and we did bad: The impact of collective versus private emotions on pro-environmental food consumption. Food Research International, 76(2), 261-268.

Paasovaara, R., Luomala, H. T., Pohjanheimo, T., \& Sandell, M. (2012). Understanding consumers' brand $\square$ induced food taste perception: A comparison of 'brand familiarity'and 'consumer value-brand symbolism (in) congruity'-accounts. Journal of Consumer Behaviour, 11(1), 11-20.

Padel, S., \& Foster, C. (2005). Exploring the gap between attitudes and behaviour: Understanding why consumers buy or do not buy organic food. British Food Journal, 107(8), 606-625.

Park, J. K., \& John, D. R. (2014). I think I can, I think I can: Brand use, self-efficacy, and performance. Journal of Marketing Research, 51(2), 233-247.

Plassmann, H., Ramsøy, T. Z., \& Milosavljevic, M. (2012). Branding the brain: A critical review and outlook. Journal of Consumer Psychology, 22(1), 18-36.

Pohjanheimo, T., Paasovaara, R., Luomala, H., \& Sandell, M. (2010). Food choice motives and bread liking of consumers embracing hedonistic and traditional values. Appetite, 54(1), 170-180.

Puska, P., Kurki, S., Lähdesmäki, M., Siltaoja, M., \& Luomala, H. (2016). Male-male status signaling through favoring organic foods: Is the signaler perceived and treated as a friend or a foe? Psychology \& Marketing, 28(8), 843-855.

Rana, J., \& Paul, J. (2017). Consumer behavior and purchase intention for organic food: A review and research agenda. Journal of Retailing and Consumer Services, 38, 157-165.

Reisch, L., Eberle, U., \& Lorek, S. (2013). Sustainable food consumption: an overview of contemporary issues and policies. Sustainability: Science, Practice, \& Policy, 9(2), 725 . 
Roberts, G. (1998). Competitive altruism: From reciprocity to the handicap principle. Proceedings of the Royal Society of London, Series B, 265, 427-431.

Rousmans, S., Robin, O., Dittmar, A., \& Vernet-Maury, E. (2000). Autonomic nervous system responses associated with primary tastes. Chemical Senses, 25(6), 709-718.

Rucker, D. D., \& Galinsky, A. D. (2008). Desire to acquire: Powerlessness and compensatory consumption. Journal of Consumer Research, 35(2), 257-267.

Russell, S. V., \& Freidrich, E. (2015). The relationship between emotions and workplace pro environmental behaviors. In J. Robertson, \& J. Barling (Eds.), The psychology of green organizations (pp. 141-163). New York: Oxford University Press.

Saad, G. (2016). On the method of evolutionary psychology and its applicability to consumer research. Journal of Marketing Research, 54(3), 464-477.

Scalco, A., Noventa, S., Sartori, R., \& Ceschi, A. (2017). Predicting organic food consumption: A meta-analytic structural equation model based on the theory of planned behavior. Appetite, 112(1), 235-248.

Schleenbecker, R., \& Hamm, U. (2013). Consumers' perception of organic product characteristics. A review. Appetite, 71(1), 420-429.

Schlosser, A. E. (2015). The sweet taste of gratitude: Feeling grateful increases choice and consumption of sweets. Journal of Consumer Psychology, 25(4), 561-576.

Schouteten, J. J., Gellynck, X., De Bourdeaudhuij, I., Sas, B., Bredie, W. L. P., Perez-Cueto, F. J. A., \& De Steur, H. (2017). Comparison of response formats and concurrent hedonic measures for optimal use of the EmoSensory ${ }^{\circledR}$ Wheel. Food Research International, 93, 33-42.

Schwartz, S. H. (2010). Basic values: How they motivate and inhibit prosocial behavior. Prosocial Motives, Emotions, and Behavior: The Better Angels of our Nature, 14, $221-$ 241.

Schösler, H., de Boer, J., Boersema, J. J., \& Aiking, H. (2015). Meat and masculinity among young Chinese, Turkish and Dutch adults in the Netherlands. Appetite, 89(1), 152-159.

Sengupta, J., \& Zhou, R. (2007). Understanding impulsive eaters' choice behaviors: The motivational influences of regulatory focus. Journal of Marketing Research, 44(2), 297-308.

Sexton, S. E., \& Sexton, A. L. (2014). Conspicuous conservation: The Prius halo and willingness to pay for environmental bona fides. Journal of Environmental Economics and Management, 67(3), 303-317.

Sirgy, M. J. (1982). Self-concept in consumer behavior: A critical review. Journal of Consumer Research, 9(3), 287-300.

Soler, M. (2012). Costly signaling, ritual and cooperation: Evidence from Candomblé, an Afro Brazilian religion. Evolution and Human Behavior, 33(4), 346-356.

Spinelli, S., Masi, C., Dinnella, C., Zoboli, G. P., \& Monteleone, E. (2014). How does it make you feel? A new approach to measuring emotions in food product experience. Food Quality and Preference, 37, 109-122.

Stöckli, S., Stämpfli, A. E., Messner, C., \& Brunner, T. A. (2016). An (un)healthy poster: When environmental cues affect consumers' food choices at vending machines. Appetite, 96(1), 368-374.

Thøgersen, J. (2017). Sustainable food consumption in the nexus between national context and private lifestyle: A multi-level study. Food Quality and Preference, 55, 16-25.

Thøgersen, J., Jorgensen, A-K., \& Sandager, S. (2012). Consumer decision making regarding a "green" everyday product. Psychology \& Marketing, 29(4), 187-197.

Thomson, D. M. H. (2007). SensoEmotional optimisation of food products and brands. In H. MacFie (Eds.), Consumer-led food product development (pp. 281-303). Cambridge: Woodhead Publishing Limited. 
Thomson, D. M. H., \& Crocker, C. (2015). Application of conceptual profiling in brand, packaging and product development. Food Quality and Preference, 40, 343-353.

Thomson, D. M. H., Crocker, C., \& Marketo, G. (2010). Linking sensory characteristics to emotions: An example using dark chocolate. Food Quality and Preference, 21(8), 1117-1125.

Tukker, A. (2015). Priorities for sustainable consumption policies. In L. A. Reisch, \& J. Thøgersen (Eds.), Handbook of research on sustainable consumption (pp.145-160). Cheltenham, UK: Edward Elgar Publishing.

Uziel, L. (2007). Individual differences in the social facilitation effect: A review and metaanalysis. Journal of Research in Personality, 41(3), 579-601.

Van der Wal, A. J., Van Horen, F., \& Grinstein, A. (2016). The paradox of 'green to be seen': Green high-status shoppers excessively use (branded) shopping bags. International Journal of Research in Marketing, 33(1), 216-219.

Van Doorn, J., \& Verhoef, P. C. (2011). Willingness to pay for organic products: Differences between virtue and vice foods. International Journal of Research in Marketing, 28(3), 167-180.

Van Vugt, M., \& Iredale, W. (2013). Men behaving nicely: Public goods as peacock tails. British Journal of Psychology, 104(1), 3-13.

Vidal, L., Ares, G., \& Jaeger, S. R. (2016). Use of emoticon and emoji in tweets for foodrelated emotional expression. Food Quality and Preference, 49, 119-128.

Vieitez, I., Gámbaro, A., Callejas, N., Miraballes, M., \& Irigaray, B. (2014). Consumer perception of goat cheese using word association technique. Journal of Food Science and Engineering, 4(3), 120-130.

Wang, J., \& Wallendorf, M. (2006). Materialism, status signaling and product satisfaction. Journal of the Academy of Marketing Science, 34(4), 494-505.

Webster, C., Chakrabarty, S., \& Kinard, B. R. (2016). The effects of motivational priming on food portion size behavior. Journal of Foodservice Business Research, 19(1), 39-55.

Wheeler, S. C., \& Berger, J. (2007). When the same prime leads to different effects. Journal of Consumer Research, 34(3), 357-368.

Wilson, A. L., Buckley, E., Buckley, J. D., \& Bogomolova, S. (2016). Nudging healthier food and beverage choices through salience and priming. Evidence from a systematic review. Food Quality and Preference, 51, 47-64.

Wu, J., Balliet, D., \& Van Lange, P. A. M. (2016). Reputation management: Why and how gossip enhances genorisity. Evolution and Human Behavior, 37(3), 193-201.

Zahavi, A. (1975). Mate selection - A selection for a handicap. Journal of Theoretical Biology, 53(1), 205-214. 